\title{
Antimicrobial use on Canadian dairy farms
}

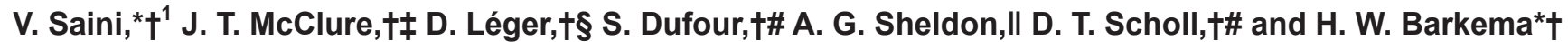 \\ *Department of Production Animal Health, University of Calgary, Calgary, Alberta, T2N 4N1, Canada \\ †Canadian Bovine Mastitis Research Network, C. P. 5000, St-Hyacinthe, Québec, J2S 7C6, Canada \\ ‡Department of Health Management, Atlantic Veterinary College, University of Prince Edward Island, Charlottetown, Prince Edward Island, \\ C1A 4P3, Canada \\ §Public Health Agency of Canada, Laboratory for Foodborne Zoonoses, Guelph, Ontario, N1G 5B2, Canada \\ \#Department of Pathology and Microbiology, Faculty of Veterinary Medicine, University of Montreal, Saint-Hyacinthe, Québec, J2S 7C6, Canada \\ IIDepartment of Mathematics and Statistics, University of Calgary, Calgary, Alberta, T2N 4N1, Canada
}

\section{ABSTRACT}

Antimicrobial use (AMU) data are critical for formulating policies for containing antimicrobial resistance. The present study determined AMU on Canadian dairy farms and characterized variation in AMU based on herd-level factors such as milk production, somatic cell count, herd size, geographic region and housing type. Drug use data were collected on 89 dairy herds in 4 regions of Canada, Alberta, Ontario, Québec, and the Maritime provinces (Prince Edward Island, New Brunswick, and Nova Scotia) for an average of $540 \mathrm{~d}$ per herd. Dairy producers and farm personnel were asked to deposit empty drug containers into specially provided receptacles. Antimicrobial use was measured as antimicrobial drug use rate (ADUR), with the unit being number of animal defined-daily doses (ADD)/1,000 cow-days. Antimicrobial drug use rates were determined at farm, region, and national level. Combined ADUR of all antimicrobial classes was 14.35 ADD/1,000 cow-days nationally. National level ADUR of the 6 most commonly used antimicrobial drug classes, cephalosporins, penicillins, penicillin combinations, tetracyclines, trimethoprim-sulfonamide combinations, and lincosamides were $3.05,2.56,2.20,1.83,0.87$, and $0.84 \mathrm{ADD} / 1,000$ cow-days, respectively. Dairy herds in Ontario were higher users of third-generation cephalosporins (ceftiofur) than in Québec. Alberta dairy herds were higher users of tetracyclines in comparison to Maritimes. Antimicrobial drug use rate was higher via systemic route as compared with intramammary and other routes of administration (topical, oral, and intrauterine). The ADUR of antimicrobials used intramammarily was higher for clinical mastitis treatment than dry cow therapy. For dry cow therapy, penicillin ADUR was greater than ADUR of first-generation cephalosporins. For clinical mastitis treatment, ADUR

Received May 10, 2011.

Accepted September 8, 2011.

${ }^{1}$ Corresponding author: vsaini@ucalgary.ca of intramammary penicillin combinations was greater than ADUR of cephapirin. Herd-level milk production was positively associated with overall ADUR, ADUR of systemically administered ceftiofur, cephapirin administered for dry cow therapy, and pirlimycin administered for clinical mastitis treatment. Herd size and ADUR of systemically administered ceftiofur were also positively associated. In conclusion, $\beta$-lactams were most commonly used on Canadian dairy farms. Among antimicrobials of very high importance in human medicine, the use of fluoroquinolones was rare, whereas third-generation cephalosporins and penicillin combinations containing colistin were used very frequently on Canadian dairy farms.

Key words: antimicrobial use, antimicrobial resistance, dairy, animal defined-daily dose

\section{INTRODUCTION}

The importance of antimicrobials in human and veterinary medicine for disease prevention and control cannot be understated (Morley et al., 2005). Not only are antimicrobials indispensible tools for decreasing morbidity and mortality due to infectious diseases, their use in veterinary medicine had a profound effect on animal health and productivity (Johnston, 1998). The commercial production and use of antimicrobials after the late 1940s in animal agriculture resulted in the effective treatment of infections, previously considered to be untreatable (Prescott, 2006). Unfortunately, emergence and dissemination of antimicrobial resistance (AMR) has followed the introduction of antimicrobials.

Various national and international bodies are intensely scrutinizing the factors promoting the emergence and dissemination of resistance among microbial pathogens in humans and animals alike (WHO, 2000; CODEX, 2005). Decades of use and misuse of antimicrobials in human and veterinary medicine is considered to be the primary factor responsible for emergence of resistance in bacteria (Levy and Marshall, 2004). Although 
antimicrobial use (AMU) and overuse is common in human medicine (Paskovaty et al., 2005), an increased focus is on veterinary AMU, especially in food animals, as a potential source and disseminator of AMR in bacteria infecting humans (White and McDermott, 2001), the concern being the use of relatively larger quantities, and the similarity to antimicrobial drug classes used in human medicine (Veterinary Drug Directorate, Health Canada, 2002; Silbergeld et al., 2008). Despite the lack of scientifically sound information about adverse health aspects due to AMU in food animals (Phillips et al., 2004), global pressure to protect the efficacy of existing and new antimicrobials by decreasing the selection pressure on bacterial populations for emergence of resistant strains due to AMU is mounting. To understand the public health risks associated with the use of antimicrobials in food animals, quantitative assessment of AMU in food animals is imperative for determining AMR epidemiology. The availability of AMU data can aid in interpreting patterns and trends of AMR, serve as a basis of risk assessment of AMR, as a basis of decision-making for control measures, and to evaluate the effect of interventions for controlling AMR (WHO, 2003). Data on AMU in food animals are, therefore, becoming increasingly important for developing national and international policies to contain AMR.

International bodies such as the Food and Agriculture Organization, the Office International des Épizooties, and the World Health Organization have recommended implementing on-going and coordinated national surveillance programs for assessing AMU in food animals (Nicholls et al., 2001; WHO, 2003). Various countries including Denmark, the Netherlands, Norway, Sweden, and UK have, therefore, implemented AMU- and AMR-monitoring programs. In North America, the United States has started collecting data on AMU in dairy cattle through various surveys (Zwald et al., 2004; Sawant et al., 2005; Pol and Ruegg, 2007). Data on AMU in food animals in Canada are limited mainly to swine and beef herds (Dunlop et al., 1998; Carson et al., 2008; Gow and Waldner, 2009). Except a study conducted by Meek et al. (1986) to assess AMU on dairy farms in Ontario, a lack of information exists on AMU on Canadian dairy farms. Recently, the Canadian Integrated Program for Antimicrobial Resistance Surveillance has started collaborating with various universities to assess AMU and resistance in dairy cattle in Canada (CIPARS, 2007).

The objectives of the present study were to describe the qualitative and quantitative aspects of AMU on Canadian dairy farms and to assess the association between AMU and herd-level factors such as milk production, SCC, herd size, geographic region, and housing type.

\section{MATERIALS AND METHODS}

\section{Dairy Cattle Herd Selection}

Data for this study originated from the National Cohort of Dairy Farms of the Canadian Bovine Mastitis Research Network, which consisted of 91 commercial dairy farms located in 4 regions across Canada [Alberta, Québec, Ontario, and the Maritime Provinces (Prince Edward Island, Nova Scotia, and New Brunswick)]. Herd selection criteria for the present study have been described by Reyher et al. (2011). In short, dairy herds were selected to replicate the provincial proportion of freestall systems to within 15 percentage points and to be uniformly distributed among 3 strata of the most recent 12 -mo bulk tank SCC average $(\leq 150,000$ cells $/ \mathrm{mL}$, $>150,000$ and $\leq 300,000$ cells $/ \mathrm{mL},>300,000$ cells $/ \mathrm{mL}$ ); herds with a $3 \times$ milking schedule and herds with less than $80 \%$ (or less than 15) Holstein lactating and dry cows at the time of enrolment were excluded. Further, eligible dairy herds must have been participating in a DHI data collection program. Eligible dairy farms were identified and contacted by the regional center coordinators. Written consent to participate in the research cohort was obtained. Two dairy herds dropped out of the study at the very beginning. The average herd size of the 89 participating dairy herds was 84 cows (median: 66, range: 33-297). Herd average daily milk production per cow ranged from 25 to $39 \mathrm{~kg}$ (mean and median: $32 \mathrm{~kg}$ ). The average herd SCC ranged from 91,000 to 500,000 cells/mL (arithmetic mean: 230,000 cells/mL; median: 220,000 cells/mL). Sixty-one, 33, 5, and 1\% of these dairy herds housed lactating cows in tie-stalls, freestalls, in a bedding packed barn, and mixed barn type, respectively. On the regional level, dairy herds in Alberta had the largest average herd size (mean: 110, median: 99, range: 42-297), followed by Maritimes (mean: 87, median: 66, range: 52-234), Ontario (mean: 80, median: 67, range: 33-182), and Québec (mean: 68, median: 60 , range: $33-184$ ). The herd average daily milk production per cow $(\mathrm{kg} / \mathrm{cow})$ was similar in dairy herds in Alberta (mean: 33, median: 33, range: 27-38) and Ontario (mean: 33, median: 33, range: 26-38), followed by Maritimes (mean: 32, median: 31, range: 28-39), and Québec (mean: 30, median: 31, range: 25-34). The average herd SCC was the highest in dairy herds in Ontario (arithmetic mean: 249,000 cells/mL, median: 244,000 cells/mL, range: $93,000-500,000$ cells/mL), followed by Québec (arithmetic mean: 245,000 cells/mL, median: 229,000 cells/mL, range: $91,000-467,000$ cells/ $\mathrm{mL}$ ), Alberta (arithmetic mean: 218,000 cells/mL, median: 179,000 cells/mL, range: 116,000-355,000 cells/ $\mathrm{mL}$ ), and Maritimes (arithmetic mean: 189,000 cells/ $\mathrm{mL}$, median: 162,000 cells/mL, range: $95,000-416,000$ 
cells $(\mathrm{mL})$. An investigator and technicians in each coordinating center were responsible for the data collection activities related to farms located in that center's area.

\section{Antimicrobial Use Data Collection Methodology}

Antimicrobial use data were collected from February 2007 until December 2008. Forty-liter receptacles with round swing tops (Sterilite Corp., Townsend, MA) were placed on participating farms for collecting data for AMU. These receptacles were labeled as "drug containers only" and were placed near the drug storage area, in the milking parlor, or any place near where the treatments were normally given (near the chute, for example). Producers, farm workers, and other farm personnel were instructed to deposit the empty containers of all drugs used by him/her or the veterinarian for treatment in calves, heifers, and adult cows (dry cows and lactating cows) into these receptacles. These containers included all empty drug bottles, drug containers, lactating cow or dry cow intramammary tubes, tablet and powder containers, medicated milk replacer and feed tags, and any other drug containers used on the farms. Any remaining drug products were also placed in the receptacles. In case a drug bottle was broken, producers were instructed to put the label into the receptacle instead. Farms were visited at least once per month. The technician and students would empty the receptacle, count the empty drug bottles and record the inventory in the drug tally sheets at the dairy farm. The drug tally sheets contained information on the following: herd identification number, start and end date of the current data collection period, date of tallying drugs, product name, volume or weight of the product, and number of containers deposited in the receptacle during current data collection period.

\section{Statistical Analysis}

Drug use data were entered into a customized database (Microsoft Office Access 2006; Microsoft Corp., Redmond, WA). A random sample of the drug tally sheets (25\%) was checked manually to detect errors in data entry. Data analyses were performed using Intercooled Stata 11.1 (Intercooled Stata for Macintosh, version 11.1; Stata Corp., College Station, TX).

Antimicrobial use data were quantified in units of animal defined daily doses (ADD). The ADD (g/d) was defined as the average daily on-label dosage multiplied by the approximate weight of an adult dairy cow (BW $=600 \mathrm{~kg}$; Jensen et al., 2004) and was based on the Canadian compendium of veterinary products (CVP, 2009). Animal defined daily doses for antimicrobials indicated for heifers and calves were calculated for BW of 200 and $50 \mathrm{~kg}$, respectively. In case of trimethoprim (TMP)-sulfonamide combinations, the ADD was calculated on the basis of TMP (the constituent drug of interest) as per Grave et al. (1999). For the remaining combination compounds (e.g., penicillin combinations, intramammary preparations containing penicillin G procaine-dihydrostreptomycin sulfate-novobiocin sodium-polymyxin B sulfate), the weights of active ingredients of the constituents were summarized to determine total weight of active ingredients in the combination compound. The amounts of active ingredients given in IU were converted into milligrams as follows: 1,000 $\mathrm{IU}$ of penicillin $\mathrm{G}$ procaine $=0.6 \mathrm{mg}$ and $1,000 \mathrm{IU}$ of polymyxin $\mathrm{B}=0.1 \mathrm{mg}$ (Prescott and Dowling, 2006). Further, the antimicrobial drug use rate (ADUR) - a herd-level and time-sensitive parameter of AMU - was defined as number of ADD used on a farm per 1,000 cows per day:

$\mathrm{ADUR}=\frac{\text { Active ingredient used in the study period }(\mathrm{g}) \times 1,000}{\mathrm{ADD} \times \text { number of days in the study period }}$.

The number of days of drug use on a dairy farm in a data collection period were calculated from the starting and end date on a drug tally sheet. Total number of adult cattle (dry and lactating) at the dairy farm in the study period was also determined concurrently. Because the total number of adult cattle varied very little from month to month (as determined by DHI test-day data at each farm), an average of the total number of adult cattle per farm was calculated and multiplied with total number of days of drug use at that farm to determine farm-level cow-days. Within a region, farm-level cow-days of various farms were aggregated to obtain region-level cow-days, and later region-level cow-days were aggregated to obtain national-level cow-days.

The ADUR of various antimicrobial drug classes were determined at farm, region, and national level. Overall ADUR - the combined ADUR of all antimicrobial classes - was also determined at these 3 levels. The overall ADUR at the farm, region, and national levels were estimated by dividing the combined ADD of all antimicrobial drug classes used at a farm, in a region, and at the national level by farm-, region-, and national-level cow-days, respectively. Region-level overall ADUR was the regional estimate of AMU, whereas national level overall ADUR was the national estimate of AMU. Data from the Maritime Provinces (Prince Edward Island, Nova Scotia, and New Brunswick) were combined due to regional homogeneity so as to facilitate statistical analysis.

At the national level, statistical significance of differences in the number of ADD among various anti- 
microbial classes was evaluated by chi-squared test. Thereafter, $95 \%$ confidence intervals around ADD were calculated. Non-overlapping 95\% confidence intervals indicated statistically significant differences in ADUR among various antimicrobial classes at the national level.

Statistical significance of variation in ADUR of various antimicrobial classes was determined across 4 regions using the Kruskal-Wallis test (Null hypothesis: no differences in ADUR across 4 regions; alternative hypothesis: at least 1 of the regions is different). In case of statistically significant results, pairwise comparisons between regions were done using the Wilcoxon rank-sum test to determine pairs of regions that were statistically different. Superscripts were placed on ADUR of herds within regions in the tables; pairs of regions with different superscripts differed significantly in the distribution of ADUR from each other. Last, variation in ADUR within 4 regions was determined by evaluating differences in the number of ADD of various antimicrobial classes using chi-squared test and 95\% confidence intervals. Again, non-overlapping 95\% confidence intervals indicated statistically significant differences in ADUR of various antimicrobial classes within 4 regions.

The differences between ADUR of antimicrobial drug classes administered by the intramammary route for dry cow therapy and clinical mastitis treatment were determined using the Wilcoxon matched-pairs signedranks test. Pairwise comparisons of ADUR between barn types (tie-stalls and freestalls) were done using the Wilcoxon rank-sum test. Correlation between herdlevel ADUR and average herd-level milk production, average herd SCC, and herd size was estimated using the Spearman rank correlation coefficient. Bonferroni adjustments were done whenever multiple comparisons were made (Abdi, 2007). In all other instances, a $P$ value $<0.05$ was considered statistically significant.

\section{RESULTS}

\section{ADUR}

Among the antimicrobial drug classes used, cephalosporins (cephapirin, ceftiofur), penicillins (ampicillin, amoxicillin, penicillin $\mathrm{G}$ procaine, penicillin $\mathrm{G}$ procainepenicillin $G$ benzathine combination, and penicillin $G$ procaine-novobiocin combination), penicillin combinations (intramammary preparation containing penicillin $\mathrm{G}$ procaine-dihydrostreptomycin sulfate-novobiocin sodium-polymyxin B sulfate combination), TMPsulfonamide combinations (TMP-sulfadoxine), tetracyclines (oxytetracycline and tetracycline hydrochloride), and lincosamides (pirlimycin) were used on the major- ity of the participating dairy farms (Table 1). At the national level, cephalosporins were the antimicrobials with the highest ADUR, followed by penicillins, penicillin combinations, tetracyclines, TMP-sulfonamide combinations, and lincosamides in decreasing order.

\section{Region}

The ADUR of tetracyclines, third-generation cephalosporins (ceftiofur), and penicillins was the highest among drug classes used in Alberta, Ontario, and Québec and Maritimes, respectively (Table 2). Differences in the distribution of ADUR of third-generation cephalosporins (ceftiofur) and tetracyclines between regions were observed. Dairy herds in Ontario were significantly higher users of third-generation cephalosporins (ceftiofur) than in Québec. Alberta dairy herds were significantly higher users of tetracyclines in comparison to Maritimes.

\section{Route of Administration}

At the national level, systemically administered antimicrobials had the highest ADUR, followed by ADUR of antimicrobials administered intramammarily and, finally, antimicrobials administered by other routes (topical, oral, and intrauterine; 5.46, 5.09, and 3.79 , respectively). Similar differences were evident in Alberta and Ontario as well, with the exception of Québec where ADUR of intramammary antimicrobials was greater than ADUR of systemically administered antimicrobials and antimicrobials administered by other routes (Table 3). Further, differences in ADUR between systemic and intramammary routes were not observed for Maritimes dairy herds.

\section{Intramammary ADUR}

At the national level, penicillin combinations had the highest intramammary ADUR followed by penicillins, first-generation cephalosporins (cephapirin), and lincosamides $(2.20,1.28,0.83$, and 0.66 , respectively; Table 4). Intramammary ADUR of penicillins used for dry cow therapy was significantly higher in Québec than in Ontario (Table 5). Maritimes dairy herds were significantly higher users of intramammary first-generation cephalosporins (cephapirin) than Alberta.

\section{Systemic ADUR}

At the national level, $\beta$-lactams were the most common and fluoroquinolones were the least commonly used systemic antimicrobial drug classes, being used on $88 / 89$ and 4/89 dairy farms, respectively. Third- 
Table 1. National-level estimate of antimicrobial drug use rate [ADUR; animal defined daily doses (ADD)/1,000 cow-days] of various antimicrobial drug classes used across 89 Canadian dairy farms, 2007 to 2008

\begin{tabular}{|c|c|c|c|c|c|c|c|c|c|c|c|}
\hline \multirow[b]{2}{*}{ Drug class } & \multirow[b]{2}{*}{$\begin{array}{l}\text { Herds } \\
(\%)\end{array}$} & \multirow[b]{2}{*}{$\begin{array}{c}\mathrm{ADD}^{1} \\
(95 \% \mathrm{CI})\end{array}$} & \multirow[b]{2}{*}{$\mathrm{ADUR}^{2}$} & \multirow[b]{2}{*}{ Minimum } & \multicolumn{6}{|c|}{$\mathrm{ADUR}^{3}$ percentile } & \multirow[b]{2}{*}{ Maximum } \\
\hline & & & & & 5 th & 10th & 25 th & 50 th & 75 th & 90th & \\
\hline Cephalosporins-first generation & $76(87)$ & $3,451(3,320$ to 3,559$)$ & 0.85 & 0 & 0 & 0 & 0.10 & 0.41 & 1.38 & 2.59 & 7.07 \\
\hline Cephalosporins - third generation & $80(90)$ & $8,949(8,738$ to 9,086$)$ & 2.20 & 0 & 0 & 0 & 0.55 & 1.24 & 2.94 & 5.29 & 7.34 \\
\hline Cephalosporins - all & $87(98)$ & $12,400(11,649$ to 12,581$)$ & $3.05^{\mathrm{a}}$ & 0 & 0.27 & 0.45 & 0.99 & 2.70 & 3.74 & 6.06 & 8.94 \\
\hline Penicillins & $85(96)$ & $10,421(10,193$ to 10,601$)$ & $2.56^{\mathrm{a}}$ & 0 & 0.08 & 0.50 & 1.63 & 2.37 & 3.50 & 4.59 & 7.20 \\
\hline All $\beta$-lactams & $89(100)$ & $22,821$ ( 22,542 to 23,008$)$ & 5.62 & 0.45 & 1.41 & 2.26 & 3.36 & 5.01 & 6.63 & 9.33 & 12.87 \\
\hline Penicillin combination $^{4}$ & $84(94)$ & $8,942(8,737$ to 9,086$)$ & $2.20^{\mathrm{a}}$ & 0 & 0 & 0.05 & 0.53 & 1.65 & 2.99 & 3.93 & 19.68 \\
\hline Tetracyclines & $57(64)$ & $7,445(7,281$ to 7,572$)$ & $1.83^{\mathrm{a}}$ & 0 & 0 & 0 & 0 & 0.36 & 0.92 & 2.71 & 50.89 \\
\hline TMP-sulfa $^{5}$ & $68(76)$ & $3,539(3,378$ to 3,611$)$ & $0.87^{\mathrm{a}}$ & 0 & 0 & 0 & 0.07 & 0.52 & 1.34 & 2.33 & 3.96 \\
\hline Lincosamides & $52(58)$ & $3,414(3,261$ to 3,494$)$ & 0.84 & 0 & 0 & 0 & 0 & 0.04 & 0.73 & 2.35 & 8.91 \\
\hline Macrolides & $31(35)$ & $1,163(1,048$ to 1,223$)$ & 0.28 & 0 & 0 & 0 & 0 & 0 & 0.10 & 0.71 & 5.41 \\
\hline Phenicols & $29(33)$ & $694(640$ to 699$)$ & 0.17 & 0 & 0 & 0 & 0 & 0 & 0.15 & 0.53 & 1.21 \\
\hline Aminoglycosides & $10(11)$ & $429(349$ to 465$)$ & 0.10 & 0 & 0 & 0 & 0 & 0 & 0 & 0.09 & 1.28 \\
\hline Ionophores & $4(5)$ & 318 (232 to 349$)$ & 0.07 & 0 & 0 & 0 & 0 & 0 & 0 & 0 & 3.79 \\
\hline Fluoroquinolones & $4(5)$ & 11 (5 to 19$)$ & 0.003 & 0 & 0 & 0 & 0 & 0 & 0 & 0 & 0.15 \\
\hline Sulfonamides & $2(2)$ & $9(4$ to 17$)$ & 0.002 & 0 & 0 & 0 & 0 & 0 & 0 & 0 & 0.08 \\
\hline Linco-spectinomycin ${ }^{6}$ & $1(1)$ & $9,464(9,261$ to 9,611$)$ & 2.33 & 0 & 0 & 0 & 0 & 0 & 0 & 0 & 89.61 \\
\hline Overall & $89(100)$ & 58,249 & 14.35 & 1.76 & 3.30 & 3.63 & 6.03 & 8.67 & 14.34 & 22.58 & 105.00 \\
\hline
\end{tabular}

${ }^{\mathrm{a}}$ Antimicrobial drug use rates of the 5 most commonly used antimicrobial drug classes $(P<0.05)$.

${ }^{1}$ Number of ADD of an antimicrobial drug class. Nonoverlapping $95 \%$ confidence intervals around ADD indicate statistically significant differences in ADUR among various antimicrobial classes.

${ }^{2}$ Pairs of regions with different superscripts differed significantly in the distribution of ADUR from each other.

${ }^{3}$ Differences in ADUR among antimicrobial drug classes at the national level were determined using chi-squared test $(P<0.05)$.

는 $\quad{ }^{4}$ Intramammary preparation containing penicillin G procaine/dihydrostreptomycin sulfate/novobiocin sodium/polymyxin B sulfate.

Trimethoprim (TMP)-sulfadoxine combination.

旁 $\quad{ }^{6}$ Lincomycin-spectinomycin combination. 
Table 2. Regional level estimate of antimicrobial drug use rate (ADUR; animal defined daily doses/1,000 cow-days) by drug class on 89 dairy farms in 4 regions of Canada, 2007 to 2008

\begin{tabular}{|c|c|c|c|c|c|c|c|c|c|c|c|c|c|}
\hline \multirow[b]{2}{*}{ Drug class } & \multicolumn{3}{|c|}{ Alberta $(\mathrm{n}=17)$} & \multicolumn{3}{|c|}{ Ontario $(\mathrm{n}=27)$} & \multicolumn{3}{|c|}{ Québec $(\mathrm{n}=28)$} & \multicolumn{3}{|c|}{ Maritimes $(\mathrm{n}=17)$} & \multirow[b]{2}{*}{$P$-value ${ }^{1}$} \\
\hline & $\begin{array}{c}\text { Herds } \\
(\%)\end{array}$ & ADUR & Median & $\begin{array}{c}\text { Herds } \\
(\%)\end{array}$ & ADUR & Median & $\begin{array}{c}\text { Herds } \\
(\%)\end{array}$ & ADUR & Median & $\begin{array}{c}\text { Herds } \\
(\%)\end{array}$ & ADUR & Median & \\
\hline Cephalosporins - first generation & $15(88)$ & 0.32 & 0.30 & $21(78)$ & 0.93 & 0.42 & $24(86)$ & 0.89 & 0.42 & $16(94)$ & 1.30 & 0.82 & 0.14 \\
\hline Cephalosporins - third generation & $15(88)$ & 2.08 & 1.20 & $27(100)$ & $2.97^{\mathrm{a}}$ & 1.94 & $22(79)$ & $1.24^{\mathrm{b}}$ & 0.68 & $16(94)$ & 2.55 & 1.55 & 0.003 \\
\hline Penicillins & $16(94)$ & 2.47 & 2.31 & $25(93)$ & 2.29 & 1.81 & $28(100)$ & 2.83 & 2.92 & $16(94)$ & 2.68 & 2.67 & 0.12 \\
\hline Penicillin combination $^{2}$ & $17(100)$ & 2.73 & 2.43 & $24(89)$ & 1.63 & 1.30 & $27(96)$ & 2.17 & 1.85 & $16(94)$ & 2.34 & 1.43 & 0.34 \\
\hline Tetracyclines & $15(88)$ & $3.68^{\mathrm{a}}$ & 1.25 & $15(55)$ & 0.68 & 0.36 & $20(71)$ & 0.68 & 0.31 & $7(41)$ & $2.47^{\mathrm{b}}$ & 0 & 0.003 \\
\hline TMP-sulfa ${ }^{3}$ & $15(88)$ & 1.37 & 0.87 & $17(63)$ & 0.58 & 0.16 & $24(86)$ & 0.92 & 0.62 & $12(71)$ & 0.57 & 0.45 & 0.08 \\
\hline Lincosamides & $12(71)$ & 1.33 & 0.40 & $16(59)$ & 1.19 & 0.07 & $17(63)$ & 0.63 & 0.12 & $7(41)$ & 0.08 & 0 & 0.08 \\
\hline Macrolides & $5(29)$ & 0.44 & 0 & $11(41)$ & 0.31 & 0 & $10(36)$ & 0.31 & 0 & $5(29)$ & 0.03 & 0 & 0.72 \\
\hline Phenicols & $9(53)$ & 0.22 & 0.10 & $9(33)$ & 0.11 & 0 & $7(25)$ & 0.21 & 0 & $4(23)$ & 0.13 & 0 & 0.22 \\
\hline Aminoglycosides & $2(12)$ & 0.20 & 0 & $1(4)$ & 0.03 & 0 & $5(18)$ & 0.16 & 0 & $2(12)$ & 0.005 & 0 & 0.43 \\
\hline Ionophores & $1(6)$ & 0.20 & 0 & $2(8)$ & 0.002 & 0 & $1(4)$ & 0.10 & 0 & 0 & 0 & 0 & 0.70 \\
\hline Fluoroquinolones & $2(12)$ & 0.008 & 0 & 0 & 0 & 0 & $2(8)$ & 0.002 & 0 & 0 & 0 & 0 & 0.20 \\
\hline Sulfonamides & $1(6)$ & 0.002 & 0 & $1(4)$ & 0.005 & 0 & 0 & 0 & 0 & 0 & 0 & 0 & 0.51 \\
\hline Linco-spectinomycin ${ }^{4}$ & 0 & 0 & 0 & $1(4)$ & 8.73 & 0 & 0 & 0 & 0 & 0 & 0 & 0 & 0.51 \\
\hline All $\beta$-lactams & $17(100)$ & 4.87 & 4.00 & $27(100)$ & 6.19 & 5.57 & $28(100)$ & 4.96 & 4.85 & $17(100)$ & 6.53 & 5.70 & 0.37 \\
\hline Overall & $17(100)$ & 15.05 & 10.19 & $27(100)$ & 19.51 & 9.35 & $28(100)$ & 10.19 & 8.94 & $17(100)$ & 12.20 & 8.26 & 0.57 \\
\hline
\end{tabular}

a,b Different superscripts within a row indicate that regions differed in the distribution of antimicrobial drug use rate from each other $($ Wilcoxon rank-sum test, $P<0.05)$.

${ }^{1}$ Statistical significance of variation in distribution of ADUR across 4 regions within a drug class was determined by the Kruskal-Wallis test $(P<0.05)$.

${ }^{2}$ Intramammary preparation containing penicillin G procaine/dihydrostreptomycin sulfate/novobiocin sodium/polymyxin B sulfate.

${ }^{3}$ Trimethoprim (TMP)-sulfadoxine combination.

${ }^{4}$ Lincomycin-spectinomycin combination. 
Table 3. Regional level estimates of antimicrobial drug use rate (ADUR; animal defined daily doses/1,000 cow-days) by route of administration on 89 dairy farms in 4 regions of Canada, 2007 to 2008

\begin{tabular}{|c|c|c|c|c|c|c|c|c|c|c|c|c|c|}
\hline \multirow[b]{2}{*}{ Route } & \multicolumn{3}{|c|}{ Alberta $(\mathrm{n}=17)$} & \multicolumn{3}{|c|}{ Ontario $(\mathrm{n}=27)$} & \multicolumn{3}{|c|}{ Québec $(\mathrm{n}=28)$} & \multicolumn{3}{|c|}{ Maritimes $(\mathrm{n}=17)$} & \multirow[b]{2}{*}{$P$-value ${ }^{1}$} \\
\hline & $\begin{array}{c}\text { Herds } \\
(\%)\end{array}$ & ADUR & Median & $\begin{array}{c}\text { Herds } \\
(\%)\end{array}$ & ADUR & Median & $\begin{array}{c}\text { Herds } \\
(\%)\end{array}$ & ADUR & Median & $\begin{array}{c}\text { Herds } \\
(\%)\end{array}$ & ADUR & Median & \\
\hline Intramammary & $17(100)$ & $5.73^{\mathrm{a}}$ & 4.41 & $25(93)$ & $4.26^{\mathrm{a}}$ & 4.19 & $28(100)$ & $5.38^{\mathrm{a}}$ & 4.46 & $17(100)$ & $5.02^{\mathrm{a}}$ & 3.23 & 0.44 \\
\hline Systemic & $17(100)$ & $6.47^{\mathrm{b}}$ & 4.29 & $27(100)$ & $5.79^{\mathrm{b}}$ & 5.00 & $27(96)$ & $4.61^{\mathrm{b}}$ & 3.93 & $17(100)$ & $4.89^{\mathrm{a}}$ & 3.16 & 0.29 \\
\hline Other $^{2}$ & $8(47)$ & $2.84^{\mathrm{c}}$ & 0 & $10(37)$ & $9.46^{\mathrm{c}}$ & 0 & $5(18)$ & $0.19^{c}$ & 0 & $6(35)$ & $2.28^{\mathrm{b}}$ & 0 & 0.23 \\
\hline
\end{tabular}

${ }^{\mathrm{a}-\mathrm{c}}$ Antimicrobial drug use rates within a column with different superscripts differ (chi-squared, $P<0.05$ ).

${ }^{1}$ Statistical significance of the variation in the distribution in ADUR among 4 regions within a route of administration was determined by the Kruskal-Wallis test $(P<0.05)$.

${ }^{2}$ Other routes included topical, oral, and intrauterine route of drug administration.

Table 4. National level estimate of intramammary antimicrobial drug use rate (ADUR; animal defined daily doses/1,000 cow-days) by antimicrobial drug classes administered for dry cow therapy and clinical mastitis treatment on 89 Canadian dairy farms, 2007 to 2008

\begin{tabular}{|c|c|c|c|c|c|c|c|c|c|c|c|}
\hline \multirow[b]{3}{*}{ Drug class } & \multirow[b]{3}{*}{$\begin{array}{l}\text { National level } \\
\text { ADUR }^{1}\end{array}$} & \multicolumn{5}{|c|}{ Dry cow therapy } & \multicolumn{5}{|c|}{ Clinical mastitis therapy } \\
\hline & & \multirow[b]{2}{*}{$\begin{array}{c}\text { Herds } \\
(\%)\end{array}$} & \multirow[b]{2}{*}{ ADUR } & \multicolumn{3}{|c|}{ Percentile } & \multirow[b]{2}{*}{$\begin{array}{c}\text { Herds } \\
(\%)\end{array}$} & \multirow[b]{2}{*}{ ADUR } & \multicolumn{3}{|c|}{ Percentile } \\
\hline & & & & 25 th & 50 th & 75 th & & & 25 th & 50 th & 75th \\
\hline Cephalosporins - first generation & 0.83 & $42(47)$ & 0.27 & 0 & $0^{\mathrm{a}}$ & 0.27 & $64(72)$ & 0.56 & 0 & $0.26^{\mathrm{a}}$ & 0.82 \\
\hline Cephalosporins - third generation & 0.09 & - & - & - & - & - & $28(31)$ & 0.09 & 0 & 0 & 0.07 \\
\hline Penicillins & 1.28 & $83(93)$ & 1.28 & 0 & 1.34 & 1.84 & - & - & - & - & - \\
\hline Penicillin combination $^{2}$ & 2.20 & - & - & - & - & - & $84(94)$ & 2.20 & 0.53 & 1.65 & 2.99 \\
\hline Lincosamides & 0.66 & - & - & - & - & - & $52(58)$ & 0.66 & 0 & 0.04 & 0.70 \\
\hline Macrolides & 0.004 & $3(3)$ & 0.003 & 0 & 0 & 0 & $1(1)$ & 0.001 & 0 & 0 & 0 \\
\hline All $\beta$-lactams & 2.21 & $87(98)$ & 1.55 & 1.19 & $1.67^{\mathrm{a}}$ & 1.94 & $71(80)$ & 0.66 & 0.06 & $0.39^{\mathrm{a}}$ & 0.94 \\
\hline Overall & 5.07 & $87(98)$ & 1.55 & 1.19 & $1.67^{\mathrm{a}}$ & 1.94 & $87(98)$ & 3.52 & 1.22 & $2.68^{\mathrm{a}}$ & 4.58 \\
\hline
\end{tabular}

$\subseteq \quad$ antimicrobial drug use rates within a row differ from each other (Wilcoxon matched-pairs signed-ranks test, $P<0.05$ ).

or ${ }^{1}$ Combined ADUR of intramammary antimicrobials used for dry cow therapy and clinical mastitis treatment.

zo Intramammary preparation containing penicillin G procaine/dihydrostreptomycin sulfate/novobiocin sodium/polymyxin B sulfate. 


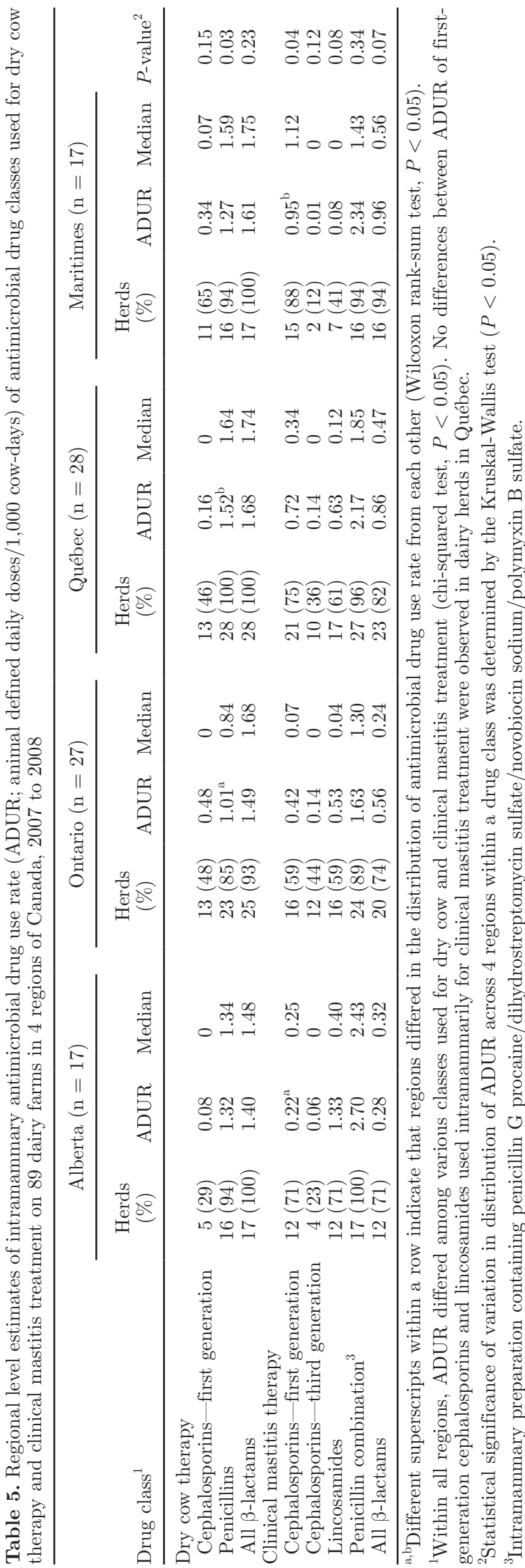

generation cephalosporins (ceftiofur) had the highest ADUR, followed by penicillins, TMP-sulfonamide combinations, and tetracyclines. Regional differences for systemic antimicrobial drugs are presented in Table 6 . Dairy herds in Québec were significantly lower users of systemic ceftiofur than Ontario and Maritimes. Further, dairy herds in Maritimes were significantly lower users of systemic tetracyclines than in Alberta.

\section{Herd-Level Factors}

The average herd milk production and herd level overall ADUR were positively correlated $(P<0.05$; Table 7; Figure 1). But, except for ADUR of systemic third-generation cephalosporins (ceftiofur), intramammary first-generation cephalosporins (cephapirin) administered for dry cow therapy and lincosamides administered for clinical mastitis treatment, correlations between average herd milk production and herd-level ADUR of specific antimicrobial drug classes were not significant and ranged from -0.16 to $0.16(P>0.10$ in all instances). The average herd SCC and herd-level overall ADUR were also not significantly correlated. The average herd size and use of systemic third-generation cephalosporins (ceftiofur) were positively correlated. Otherwise, average herd size and herd-level overall ADUR were not significantly correlated.

The herd-level overall ADUR was not significantly different between farms using tie-stalls and farms using freestalls (11.03 and 16.66, respectively; $P=0.45$ ). The ADUR of systemically administered penicillins was greater in tie-stalls than in freestalls; however, the differences were not significant (median: 1.34 and 0.61 , respectively; $P=0.06$ ). Similarly, the ADUR of intramammary penicillin combinations used for clinical mastitis treatment was also greater in tie-stalls than in freestalls; however, differences were also not significant (median: 1.85 and 1.43, respectively; $P=0.06$ ).

\section{DISCUSSION}

The present study was conducted to determine AMU on Canadian dairy farms and to identify herd-level factors that characterize variation in AMU. This was the first time that such a Canada-wide prospective study was undertaken to quantify use of antimicrobials on dairy farms. Antimicrobial drug use rate was an estimate of AMU. To compare ADUR between different farms, it was assumed that antimicrobials were used as per directions on the label, all replacement animals were born and raised on the farm (Pol and Ruegg, 2007), and that herd size remained constant over the study period. 
Table 6. Regional level estimates of systemic antimicrobial drug use rate (ADUR; animal defined daily doses/1,000 cow-days) of antimicrobial drug classes administered on 89 dairy farms in 4 regions of Canada, 2007 to 2008

\begin{tabular}{|c|c|c|c|c|c|c|c|c|c|c|c|c|c|}
\hline \multirow[b]{2}{*}{ Drug class $^{1}$} & \multicolumn{3}{|c|}{ Alberta $(\mathrm{n}=17)$} & \multicolumn{3}{|c|}{ Ontario $(\mathrm{n}=27)$} & \multicolumn{3}{|c|}{ Québec $(\mathrm{n}=28)$} & \multicolumn{3}{|c|}{ Maritimes $(\mathrm{n}=17)$} & \multirow[b]{2}{*}{$P$-value } \\
\hline & $\begin{array}{c}\text { Herds } \\
(\%)\end{array}$ & ADUR & Median & $\begin{array}{c}\text { Herds } \\
(\%)\end{array}$ & ADUR & Median & $\begin{array}{c}\text { Herds } \\
(\%)\end{array}$ & ADUR & Median & $\begin{array}{c}\text { Herds } \\
(\%)\end{array}$ & ADUR & Median & \\
\hline Cephalosporins - third generation & $15(88)$ & 2.01 & 1.20 & $27(100)$ & $2.83^{\mathrm{a}}$ & 1.93 & $19(68)$ & $1.09^{\mathrm{b}}$ & 0.55 & $16(94)$ & $2.54^{\mathrm{a}}$ & 1.55 & 0.001 \\
\hline Penicillins & $12(71)$ & 1.15 & 0.63 & $22(81)$ & 1.28 & 0.80 & $25(89)$ & 1.30 & 1.39 & $16(94)$ & 1.41 & 0.89 & 0.68 \\
\hline Tetracyclines & $15(88)$ & $1.25^{\mathrm{a}}$ & 0.72 & $15(55)$ & 0.68 & 0.36 & $20(71)$ & 0.68 & 0.31 & $6(35)$ & $0.19^{\mathrm{b}}$ & 0 & 0.006 \\
\hline TMP-sulfa ${ }^{3}$ & $15(88)$ & 1.37 & 0.87 & $17(63)$ & 0.58 & 0.16 & $24(86)$ & 0.92 & 0.62 & $12(71)$ & 0.57 & 0.45 & 0.08 \\
\hline Macrolides & $5(29)$ & 0.44 & 0 & $9(33)$ & 0.30 & 0 & $10(36)$ & 0.31 & 0 & $3(18)$ & 0.03 & 0 & 0.43 \\
\hline Phenicols & $9(53)$ & 0.22 & 0.10 & $9(33)$ & 0.11 & 0 & $7(25)$ & 0.21 & 0 & $4(23)$ & 0.13 & 0 & 0.22 \\
\hline Aminoglycosides & 0 & 0 & 0 & 0 & 0 & 0 & $1(4)$ & 0.07 & 0 & 0 & 0 & 0 & 0.53 \\
\hline Fluoroquinolones & $2(12)$ & 0.008 & 0 & 0 & 0 & 0 & $2(7)$ & 0.002 & 0 & 0 & 0 & 0 & 0.20 \\
\hline All $\beta$-lactams & $17(100)$ & 3.17 & 3.12 & $27(100)$ & 4.11 & 3.30 & $27(96)$ & 2.39 & 1.75 & $17(100)$ & 3.95 & 2.14 & 0.16 \\
\hline
\end{tabular}

${ }^{\mathrm{a}, \mathrm{b}}$ Different superscripts within a row indicate that regions differed in the distribution of antimicrobial drug use rate from each other $($ Wilcoxon rank-sum test, $P<0.05)$.

${ }^{1}$ Within all regions, ADUR differed among various antimicrobial classes (chi-squared $\left.P<0.05\right)$. However, no differences in ADUR between penicillins and tetracyclines, and between tetracyclines and trimethoprim (TMP)-sulfadoxine combinations were observed in dairy herds in Alberta.

${ }^{2}$ Statistical significance of variation in distribution of ADUR across 4 regions within a drug class was determined by the Kruskal-Wallis test $(P<0.05)$.

${ }^{3}$ TMP-sulfadoxine combination.

Table 7. Correlations between herd level antimicrobial drug use rate [ADUR; animal defined daily doses (ADD)/1,000 cow-days] and average herd milk production, average herd SCC, and average herd size on 89 Canadian dairy farms, 2007 to 2008

\begin{tabular}{|c|c|c|c|c|c|c|}
\hline \multirow[b]{2}{*}{$\begin{array}{l}\text { Antimicrobial drug use rate } \\
(\mathrm{ADD} / 1,000 \text { cow-days })\end{array}$} & \multicolumn{6}{|c|}{ Spearman's rho ( $P$-value $)$} \\
\hline & $\begin{array}{l}\text { Milk } \\
\text { production }\end{array}$ & $(P$-value $)$ & $\mathrm{SCC}$ & $(P$-value $)$ & $\begin{array}{l}\text { Herd } \\
\text { size }\end{array}$ & $(P$-value $)$ \\
\hline Overall ADUR & 0.21 & 0.04 & 0.07 & 0.49 & 0.01 & 0.97 \\
\hline Systemic cephalosporins - third generation & 0.27 & 0.01 & -0.01 & 0.95 & 0.25 & 0.01 \\
\hline Systemic penicillins & 0.08 & 0.44 & 0.01 & 0.90 & -0.19 & 0.07 \\
\hline Systemic tetracyclines & 0.09 & 0.37 & 0.09 & 0.40 & 0.05 & 0.59 \\
\hline Systemic trimethoprim-sulfonamide combinations & 0.16 & 0.12 & 0.14 & 0.18 & -0.07 & 0.47 \\
\hline Intramammary cephalosporins - first generation (dry cow therapy) & 0.22 & 0.03 & -0.03 & 0.71 & -0.06 & 0.53 \\
\hline Intramammary penicillins (dry cow therapy) & -0.16 & 0.11 & -0.03 & 0.77 & 0.05 & 0.60 \\
\hline Intramammary cephalosporins - first generation (clinical mastitis therapy) & 0.04 & 0.66 & 0.00 & 0.98 & -0.09 & 0.35 \\
\hline Intramammary penicillin combination (clinical mastitis therapy) ${ }^{1}$ & 0.14 & 0.16 & 0.16 & 0.12 & 0.05 & 0.61 \\
\hline Intramammary lincosamides (clinical mastitis therapy) & 0.27 & 0.01 & -0.08 & 0.42 & -0.01 & 0.88 \\
\hline
\end{tabular}

Intramammary preparation containing penicillin G procaine/dihydrostreptomycin sulfate/novobiocin sodium/polymyxin B sulfate. 


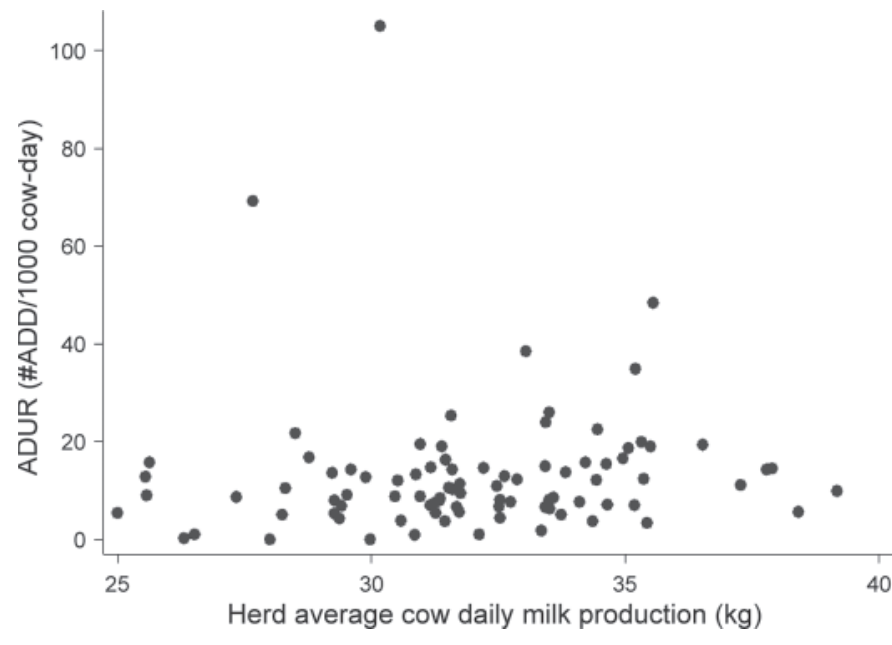

Figure 1. Relationship between antimicrobial drug use rate [ADUR: animal defined daily dose (ADD)/1,000 cow-days] and herd average cow daily milk production $(\mathrm{kg})$ on 89 Canadian dairy farms in 6 provinces, 2007 to 2008 .

The ADUR data were highly skewed and, therefore, nonparametric tests were used to determine statistical significance of differences in the distribution of ADUR of various antimicrobial classes. Kruskal-Wallis and Wilcoxon rank-sum tests compared entire distributions of ADUR across 4 regions and between pairs of regions, respectively, rather than a particular test statistic as mean or median. Medians were reported to indicate the direction of differences in the skewed distributions. The Spearman rank correlation coefficient, a nonparametric measure of statistical dependence between the ranked variables, was estimated to determine correlations between herd-level ADUR and average herd-level milk production, average herd SCC, and herd size.

Various sources of determining information on AMU in food animal production systems include wholesalers, pharmacists, veterinarians, feed companies, and animal producers; accessibility and accuracy of the information collected as such depends upon the objectives of the study and data available (Chauvin et al., 2001). Methods used commonly for measuring on-farm AMU include mailing out cross-sectional surveys to producers (Spicer et al., 1994; Sawant et al., 2005), filling in of treatment diaries by dairy producers (Meek et al., 1986), and inventory of empty antimicrobial containers (Carson et al., 2008). However, inadequate response to the self-reported surveys, recall bias, producer noncompliance, and under-recording/incomplete/inaccurate/ unverifiable recording in the treatment diaries by producers are some of the issues associated with methods of AMU measurement (Kaneene and Ahl, 1987; Zwald et al., 2004; Sawant et al., 2005; Raymond et al., 2006; Pol and Ruegg, 2007). Due to difficulty in collecting, validating, and interpreting the recorded AMU data, an audit system of the empty antimicrobial containers was preferred over treatment diaries by Carson et al. (2008), and therefore, this system was employed in the present study for the same reasons as well. The prospective design of the study and placement of receptacles for collecting antimicrobials prevented issues of recall bias, and of incomplete and unverifiable records associated with self-reported surveys and treatment diaries. The audit system was a producer- and technician-friendly system to determine herd-level AMU. However, it is quite likely that producers might have forgotten to put all of the empty antimicrobials in these receptacles. Still, the authors would recommend using such a system for collecting herd-level information on AMU. However, electronic recorders for recording animal-level use of antimicrobials are also needed. At the animal level, electronic recording systems would promote better accuracy and traceability of treatments (Singer et al., 2006; Carson et al., 2008; Menéndez González et al., 2010).

The veterinary analog of defined daily dose (ADD) holds a specific relevance in pharmaco-epidemiologic studies of drug consumption. Animal defined daily dose corrects for differences in the therapeutic potency of active ingredients and formulations of the antimicrobial drugs (Chauvin et al., 2001). Further, the ADD considers pharmacological activity of an antimicrobial agent in exerting selection pressure applied to a dairy farm environment. The ADD has been used to describe veterinary AMU at the country level and the farm level as a unit for standardized drug utilization (Grave et al., 1999; Grave et al., 2004; Jensen et al., 2004; Pol and Ruegg, 2007; Carson et al., 2008). In the context of dairy farming in Canada, the use of ADD at farm level is a novel approach for studying on-farm antimicrobial use. Nevertheless, ADD used in the present study cannot be compared with similar units used in other studies due to variation in pharmacopoeia and BW of farm animals assumed in the calculation protocol. Further, ADD only considers average on-label recommended dosage for the indicated conditions and fails to consider extra-label drug use. Therefore, if the extralabel drug usage varies between geographical regions, ADD would fail to reflect this difference. Further, ADD fails to distinguish between the treatment protocol of 1 to 2 syringes per cow in $24 \mathrm{~h}$ for clinical mastitis treatment and the protocol of 4 tubes per cow for dry cow therapy. Even though the number of syringes used per animal for dry cow therapy is much more than for clinical mastitis treatment, both treatment protocols would still constitute a single ADD. In fact, ADD is just a scaling factor and an index measure for comparing AMU between different farms (Jensen et al., 2004).

Overall ADUR was found to be positively but weakly correlated with herd-level milk production. Overall 
ADUR was not significantly associated with average herd SCC and herd size, barn type, or geographical region. Similarly, Zwald et al. (2004) found no association between herd size and antimicrobial use in their study. However, the use of some specific antimicrobial drug classes correlated with herd milk production level and herd size. For example, positive correlation between herd level milk production and ADUR of systemic third-generation cephalosporins (ceftiofur), intramammary first-generation cephalosporins (cephapirin) used for dry cow therapy, and intramammary lincosamides administered for clinical mastitis treatment was evident in the present study; however, it is highly likely that such an association is confounded by higher incidence of mastitis and (or) differences in producers' attitudes and preferences about mastitis treatment on these farms. Similarly, the ADUR of systemic third-generation cephalosporins (ceftiofur) and average herd size was also correlated. Tie-stalls and freestalls were the most common housing types on Canadian dairy farms. Overall ADUR was not associated with barn type. However, ADUR of penicillin combinations used for intramammary clinical mastitis treatment, and systemically administered penicillins tended to be greater in tie-stall dairy herds than in freestalls, even though such differences were not significant. Incidence of clinical mastitis and distribution of mastitis-causing pathogens varied by barn-type (Olde Riekerink et al., 2008) and bulk milk SCC (Barkema et al., 1998), thereby potentially explaining heterogeneity in AMU between farms within and across regions. Interestingly, correlation between intramammary ADUR and average herd SCC was not observed in the present study. It is plausible that SCC, being an intermediate variable on causal pathway between incidence of mastitis (subclinical or clinical) and intramammary ADUR, does not have an independent effect on ADUR per se or the effect is negligible. Data on incidence of mastitis should, therefore, be collected to evaluate the relationship between SCC and ADUR in antimicrobial drug utilization studies. In addition, information on herd-level management practices that could potentially affect incidence of disease, and therefore ADUR, should be collected as well.

Variation in the use of antimicrobials among dairy farms was evident in the present study as also observed by Pol and Ruegg (2007) and Menéndez González et al. (2010). Cephalosporins, penicillins, penicillin combinations, and tetracyclines were the most commonly used antimicrobial drug classes on Canadian dairy farms, whereas macrolides and fluoroquinolones were infrequently used; these observations are similar to what was found on Dutch dairy farms (MARAN, 2008). Generally speaking, $\beta$-lactams were used on all dairy farms, and constituted the highest proportion of AMU-similar to what is found on US dairy farms (Sawant et al., 2005; Raymond et al., 2006). Within $\beta$-lactams, cephalosporins had greater ADUR than penicillins. Within cephalosporins, third-generation cephalosporins (ceftiofur) had greater ADUR than first-generation cephalosporins (cephapirin); Pol and Ruegg (2007) and Zwald et al. (2004) had also reported the frequent use of ceftiofur for treating various diseases on the majority of dairy farms. Ceftiofur, when administered systemically as per indicated dose and duration, does not have a withdrawal period for milk or meat (Erskine et al., 2002), and is, therefore, an attractive antimicrobial to use on dairy farms. The use of third- and fourth-generation cephalosporins (ceftiofur in particular) tended to increase on Dutch dairy farms as well (MARAN, 2008).

Health Canada has categorized antimicrobial drug classes considering that some antimicrobial classes are considered more important in treatment of serious bacterial infections, and that development of resistance against these classes will have more serious consequences for human health (Health Canada, 2009). These categories based on importance in human medicine, are as follows: category I: very high importance [e.g., thirdgeneration cephalosporins, penicillin combinations containing polymyxin (colistin), and fluoroquinolones]; category II: high importance (e.g., first-generation cephalosporins, aminoglycosides, lincosamides, macrolides, penicillins, and TMP-sulfonamide combinations); category III: medium importance (e.g., phenicols, tetracyclines, and sulfonamides); and category IV: low importance (e.g., ionophores). In the present study, category II drug classes were used most on Canadian dairy farms, followed by category I, category IV, and category III antimicrobials.

In case of antimicrobials administered via systemic route, significant differences in ADUR of third-generation cephalosporins (ceftiofur) and tetracyclines were evident across the 4 studied regions. Dairy herds in Maritimes were lower users of systemic tetracyclines in comparison to Alberta, whereas dairy herds in Québec were lower users of third-generation cephalosporins (ceftiofur) than Ontario and Maritimes. Penicillins, novobiocin, and cephalosporins (ceftiofur, in particular) were antimicrobials of choice in Ontario dairy herds, consistent with what was previously observed by Léger et al. (2003). Differences in antimicrobial prescription policy between provinces can potentially explain geographical variation in AMU. For example, antimicrobials cannot be purchased without veterinary prescription in Québec, unlike the rest of Canada where some antimicrobials can be purchased. In addition, at least 1 visit to the dairy farm in the preceding 12 mo by the 
veterinarian is required to prescribe a veterinary compound in Québec. These regulations might influence the type of antimicrobial use in this province.

Intramammary dry cow therapy was adopted in almost all (98\%) of the dairy herds in this study, an observation similar to those of Zwald et al. (2004), Raymond et al. (2006), and Pol and Ruegg (2007). Among intramammary drugs, antimicrobials were used in greater proportion for clinical mastitis treatment as compared with dry cow therapy, as also observed on US dairy farms (Pol and Ruegg, 2007) and Finnish dairy farms (FINRES-Vet, 2005-2006). First-generation cephalosporins (cephapirin) and penicillins (cloxacillin, and penicillin $\mathrm{G}$ procaine-novobiocin combination) were most commonly used for dry cow therapy, an observation similar to those of Raymond et al. (2006) and Pol and Ruegg (2007). Further, penicillin combinations were used in higher proportion on the majority of dairy farms relative to first-generation cephalosporins (cephapirin) and lincosamides (pirlimycin) for intramammary clinical mastitis treatment, unlike in the study conducted by Pol and Ruegg (2007), where first-generation cephalosporins (cephapirin) and lincosamides (pirlimycin) were the most frequently used intramammary products for clinical mastitis treatment. However, penicillin combinations are not available as intramammary mastitis treatment preparations in lactating cows in the United States. It can be concluded that $\beta$-lactams are still the most commonly used intramammary preparations for prevention and treatment of mastitis, as observed in other studies as well (Zwald et al., 2004; Sato et al., 2005; Sawant et al., 2005; Pol and Ruegg, 2007).

Dairy herds in this study were not randomly selected. However, these herds were representative of their respective dairy herd populations in some important parameters (Reyher et al., 2011). Further, due to a lack of information on herd size in terms of calf and heifer inventories on each farm, the ADUR overestimate the actual AMU on farms. Furthermore, inference from this herd-level study could not be applied at the animal level due to ecological fallacy. Also, the study excluded $3 \times$ milking herds, which have higher milk production and potentially lower clinical mastitis incidence (Smith et al., 2002) and, therefore, lower drug use. In general, the AMU data can be used as a baseline to monitor temporal trends in antimicrobial drug utilization on Canadian dairy farms, and also to evaluate the effect of interventions for promoting judicious use of antimicrobials in Canadian dairy farming.

\section{CONCLUSIONS}

Variation in antimicrobial use between dairy farms within and across 4 regions was evident. Overall ADUR increased with increasing herd-level milk production, but was not associated with average herd SCC, herd size, barn type, and geographical region. $\beta$-Lactams were the most commonly used antimicrobials on Canadian dairy farms. Among antimicrobials of very high importance in human medicine, the use of fluoroquinolones was rare, whereas third-generation cephalosporins and penicillin combinations containing colistin were used very frequently on Canadian dairy farms. Coordinated ongoing surveillance of antimicrobial use is needed to determine the effect of antimicrobial use on antimicrobial resistance.

\section{ACKNOWLEDGMENTS}

The authors thank technicians Adele Veinot, Andrea Wasko, Anke Wellen, Francois Dubois, Meliza Morris, Mike MacLean, Natasha Robinson, and Theresa Andrews (all from Canadian Bovine Mastitis Research Network, St-Hyacinthe, QC, Canada) for collection of drug tally sheets, Vicky Stagg (University of Calgary, Calgary, AB, Canada) for statistical programming, and Trevor DeVries, Jean-Philippe Roy, Luc DesCôteaux, Ian Dohoo, Greg Keefe, and Kristen Reyher (all from Canadian Bovine Mastitis Research Network, St-Hyacinthe, QC, Canada) for coordination of the National Dairy Farm Cohort regional centers. This research was financed by the Natural Science and Engineering Research Council of Canada (Ottawa, ON, Canada); Alberta Milk (Edmonton, AB, Canada); Dairy Farmers of New Brunswick, Nova Scotia, Ontario, and Prince Edward Island; Novalait Inc. (Quebec, QC, Canada); Dairy Farmers of Canada (Ottawa, ON, Canada); Canadian Dairy Network (Guelph, ON, Canada); Agriculture and Agri-Food Canada (Ottawa, ON, Canada); Public Health Agency of Canada (Ottawa, ON, Canada); Technology PEI Inc. (Charlottetown, PEI, Canada); Université de Montréal (Montréal, QC, Canada), and University of Prince Edward Island (Charlottetown, PEI, Canada), through the Canadian Bovine Mastitis Research Network.

\section{REFERENCES}

Abdi, H. 2007. Bonferroni and Šidák corrections for multiple comparisons. Pages 103-106 in Encyclopedia of Measurement and Statistics. N. J. Salkind, ed. Sage Publications Inc., Thousand Oaks, CA.

Barkema, H. W., Y. H. Schukken, T. J. G. M. Lam, M. L. Beiboer, H. Wilmink, G. Benedictus, and A. Brand. 1998. Incidence of clinical mastitis in dairy herds grouped in three categories by bulk milk somatic cell counts. J. Dairy Sci. 81:411-419.

Carson, C. A., R. Reid-Smith, R. J. Irwin, W. S. Martin, and S. A. McEwen. 2008. Antimicrobial use on 24 beef farms in Ontario. Can. J. Vet. Res. 72:109-118.

Chauvin, C., F. Madec, D. Guillemot, and P. Sanders. 2001. The crucial question of standardization when measuring drug consumption. Vet. Res. 32:533-543. 
CIPARS. 2007. Canadian Integrated Program for Antimicrobial Resistance Surveillance. Page 81, Box 7. Accessed Aug. 10, 2011. http:// www.phac-aspc.gc.ca/cipars-picra/pdf/cipars-picra-2007-eng.pdf.

CODEX. 2005. Code of practice to minimize and contain antimicrobial resistance. Report number CAC/RCP 61-2005, 2005. Accessed Aug. 10, 2011. www.codexalimentarius.net/download/standards/10213/CXP_061e.pdf.

CVP. 2009. Canadian Compendium of Veterinary Products. 11th ed. North American Compendiums. Accessed Aug. 10, 2011. http:// naccvp.com.

Dunlop, R. H., S. A. McEwen, A. H. Meek, W. D. Black, R. C. Clarke, and R. M. Friendship. 1998. Individual and group antimicrobial usage rates on 34 farrow-to-finish swine farms in Ontario, Canada. Prev. Vet. Med. 34:247-264.

Erskine, R. J., P. C. Bartlett, J. L. VanLente, and C. R. Phipps. 2002. Efficacy of systemic ceftiofur as a therapy for severe clinical mastitis in dairy cattle. J. Dairy Sci. 85:2571-2575.

FINRES-Vet. 2005-2006. Finnish Veterinary Antimicrobial Resistance Monitoring and Consumption of Antimicrobial Agents. Finnish Food Safety Authority Evira, Helsinki, Finland. Accessed Aug. 10, 2011. http://www.evira.fi/portal/en/evira/publications/?a=v iew\&productId $=178$.

Gow, S. P., and C. L. Waldner. 2009. Antimicrobial drug use and reason for treatment in 203 Western Canadian cow-calf herds during calving season. Prev. Vet. Med. 90:55-65.

Grave, K., C. Greko, L. Nilsson, K. Odensvik, T. Mørk, and M. Rønning. 1999. The usage of veterinary antibacterial drugs for mastitis in cattle in Norway and Sweden during 1990-1997. Prev. Vet. Med. 42:45-55.

Grave, K., M. C. Kaldhusdal, H. Kruse, L. M. F. Harr, and K. Flatlandsmo. 2004. What has happened in Norway after the ban of avoparcin? Consumption of antimicrobials by poultry. Prev. Vet. Med. 62:59-72.

Health Canada. 2009. Categorization of antimicrobial drugs based on importance in human medicine. Accessed Aug. 10, 2011. http:// www.hc-sc.gc.ca/dhp-mps/consultation/vet/consultations/amr_ ram_hum-med-rev-eng.php.

Jensen, V. F., E. Jacobsen, and F. Bager. 2004. Veterinary antimicrobial-usage statistics based on standardized measures of dosage. Prev. Vet. Med. 64:201-215.

Johnston, A. M. 1998. Use of antimicrobial drugs in veterinary practice. BMJ 317:665-667.

Kaneene, J. B., and A. S. Ahl. 1987. Drug residues in dairy cattle industry: Epidemiological evaluation of factors influencing their occurrence. J. Dairy Sci. 70:2176-2180.

Léger, D., D. Kelton, K. Lissemore, R. Reid-Smith, S. W. Martin, and N. Anderson. 2003. Antimicrobial drug use by dairy veterinarians and free-stall producers in Ontario. Pages 318-319 in Proc. National Mastitis Council Meeting. National Mastitis Council Inc., Madison, WI.

Levy, S. B., and B. Marshall. 2004. Antibacterial resistance worldwide: Causes, challenges and responses. Nat. Med. 10:S122-S129.

MARAN. 2008. MARAN-2008-Monitoring of Antimicrobial Resistance and Antibiotic Usage in Animals in the Netherlands in 2008. Accessed Aug. 10, 2011. http://www.cvi.wur.nl/NR/rdonlyres/DDA15856-1179-4CAB-BAC6-28C4728ACA03/110563/ MARAN__2008__definitief_corrected.pdf.

Meek, A. H., S. W. Martin, J. B. Stone, I. McMillan, J. B. Britney, and D. G. Grieve. 1986. The relationship among current management systems, production, disease and drug usage on Ontario dairy farms. Can. J. Vet. Res. 50:7-14.

Menéndez González, S., A. Steiner, B. Gassner, and G. Regula. 2010. Antimicrobial use in Swiss dairy farms: Quantification and evaluation of data quality. Prev. Vet. Med. 95:50-63.

Morley, P. S., M. D. Apley, T. E. Besser, D. P. Burney, P. J. FedorkaCray, M. G. Papich, J. L. Traub-Dargatz, and J. S. Weese. 2005. Antimicrobial drug use in veterinary medicine. J. Vet. Intern. Med. 19:617-629.

Nicholls, T., J. Acar, F. Anthony, A. Franklin, R. Gupta, Y. Tamura, S. Thompson, E. J. Threlfall, D. Vose, M. van Vuuren, D. G.
White, H. C. Wegener, and M. L. Costarrica. 2001. Antimicrobial resistance: Monitoring the quantities of antimicrobials used in animal husbandry. Rev. Sci. Tech. 20:841-847.

Olde Riekerink, R. G. M., D. T. Scholl, D. F. Kelton, and H. W. Barkema. 2008. Incidence rate of clinical mastitis on Canadian dairy farms. J. Dairy Sci. 91:1366-1377.

Paskovaty, A., J. M. Pflomm, N. Myke, and S. K. Seo. 2005. A multidisciplinary approach to antimicrobial stewardship: Evolution into the 21st century. Int. J. Antimicrob. Agents 25:1-10.

Phillips, I., M. Casewell, T. Cox, B. De Groot, C. Friis, R. Jones, C. Nightingale, R. Preston, and J. Waddell. 2004. Does the use of antibiotics in food animals pose a risk to human health? A critical review of published data. J. Antimicrob. Chemother. 53:28-52.

Pol, M., and P. L. Ruegg. 2007. Treatment practices and quantification of antimicrobial drug usage in conventional and organic dairy farms in Wisconsin. J. Dairy Sci. 90:249-261.

Prescott, F. J. 2006. History of antimicrobial usage in agriculture: An overview. Pages 19-28 in Antimicrobial Resistance in Bacteria of Animal Origin. F. M. Aarestrup, ed. American Society of Microbiology, Washington, DC.

Prescott, F. J., and P. M. Dowling. 2006. Pages 128 and 171 in Antimicrobial Therapy in Veterinary Medicine. S. Giguère, ed. Blackwell Publishing, Ames, IA.

Raymond, M. J., R. D. Wohrle, and D. R. Call. 2006. Assessment and promotion of judicious antibiotic use on dairy farms in Washington State. J. Dairy Sci. 89:3228-3240.

Reyher, K. K., S. Dufour, H. W. Barkema, L. Des Côteaux, T. J. DeVries, I. R. Dohoo, G. P. Keefe, J. P. Roy, and D. T. Scholl. 2011. The National Cohort of Dairy Farms - A data collection platform for mastitis research in Canada. J. Dairy Sci. 94:1616-1626.

Sato, K., P. C. Bartlett, R. Erskine, and J. Kaneene. 2005. A comparison of production and management between Wisconsin organic and conventional dairy herds. Livest. Prod. Sci. 93:105-115.

Sawant, A. A., L. M. Sordillo, and B. M. Jayarao. 2005. A survey on antibiotic usage in dairy herds in Pennsylvania. J. Dairy Sci. 88:2991-2999.

Silbergeld, E. K., J. Graham, and L. B. Price. 2008. Industrial food animal production, antimicrobial resistance, and human health. Annu. Rev. Public Health 29:151-169.

Singer, R. S., R. Reid-Smith, and W. M. Sischo. 2006. Stakeholder position paper: Epidemiological perspectives on antibiotic use in animals. Prev. Vet. Med. 73:153-161.

Smith, J. W., L. O. Ely, W. M. Graves, and W. D. Gilson. 2002. Effect of milking frequency on DHI performance measures. J. Dairy Sci. 85:3526-3533.

Spicer, H. M., L. A. Goonewardene, A. O. McNeil, and W. L. Slack. 1994. Alberta dairy farm survey response. J. Dairy Sci. 77:34603472 .

Veterinary Drug Directorate, Health Canada. 2002. Uses of antimicrobials in food animals in Canada: Impact on resistance and Human health. Accessed Aug. 10, 2011. http://www.hc-sc.gc.ca/ dhp-mps/alt_formats/hpfb-dgpsa/pdf/pubs/amr-ram_final_ report-rapport_06-27-eng.pdf.

White, D. G., and P. F. McDermott. 2001. Emergence and transfer of antibacterial resistance. J. Dairy Sci. 84(Suppl.):E151-E155.

WHO. 2000. WHO global principles for the containment of antimicrobial resistance in animals intended for food. WHO, Geneva Switzerland. Accessed Aug. 10, 2011. http://whqlibdoc.who.int/ hq/2000/WHO_CDS_CSR_APH_2000.4.pdf.

WHO. 2003. Joint FAO/OIE/WHO expert workshop on non-human antimicrobial usage and antimicrobial resistance: Scientific assessment. Geneva, Switzerland, December 1-5, 2003. Accessed Aug. 10, 2011. http://www.who.int/foodsafety/publications/micro/en/ amr.pdf.

Zwald, A. G., P. L. Ruegg, J. B. Kaneene, L. D. Warnick, S. J. Wells, C. Fossler, and L. W. Halbert. 2004. Management practices and reported antimicrobial usage on conventional and organic dairy farms. J. Dairy Sci. 87:191-201. 